\title{
Factors associated with hospital admission in patients reaching the emergency department with COPD exacerbation
}

\author{
Maria Teresa García-Sanz ${ }^{*}$, Carlos Pol-Balado ', Concepción Abellás ${ }^{1}$, Juan Carlos Cánive-Gómez², \\ Diana Antón-Sanmartin ${ }^{2}$ and Francisco J González-Barcala ${ }^{3}$
}

\begin{abstract}
Background: The aim of this study was to determine the frequency of COPD exacerbations in our Emergency Department, as well as the hospitalization-related factors.

Methods: Prospective observational study conducted in the Emergency Department of Salnés County Hospital among patients admitted for COPD exacerbation. Admission predictors were determined by multivariate analysis.

Results: There were 409 exacerbations in 239 patients (79\% male, mean age 75). 57\% of exacerbations required hospitalization. Hospitalization-related factors were impaired oxygenation $(p<0.001)$, presence of neutrophilia $(p<0.01)$ and prescription of antibiotics in the Emergency Department $(p<0.05)$.

Conclusions: COPD exacerbation accounts for over 1\% of all visits to our Emergency Department. $57 \%$ of them required hospitalization. Impaired oxygenation, greater neutrophilia and prescription of antibiotics in the Emergency Department were associated with greater probability of admission.
\end{abstract}

Keywords: Admission, COPD, Emergency Department, Exacerbation

\section{Background}

Chronic Obstructive Pulmonary Disease (COPD) is a major cause of morbidity and mortality worldwide [1]. It presents exacerbations that often lead the patient to the Emergency Department (ED) and to hospitalization, contributing significantly to higher health care costs [2]. In Spain, COPD prevalence in adults aged 40-69 is 9.1\% [3]. The disease ranks fourth among causes of mortality [4] and it is responsible for $7 \%$ of hospital admissions [5]. COPD-related costs in 1998 were estimated at about $€ 1,210$ million [6].

Despite the large economic impact posed by COPD exacerbations, there is a still ongoing debate about the predictors of higher likelihood of hospitalization in patients with COPD exacerbation which have received hospital care in an ED [7-9].

Latest studies have shown a significant increase in hospital admissions for chronic obstructive respiratory disease in recent years in our region [10].

\footnotetext{
*Correspondence: maite-garcia@wanadoo.es

${ }^{1}$ Emergency Department, Salnés County Hospital, Ande-Rubiáns s/n,

Vilagarcía de Arousa, Pontevedra, Spain

Full list of author information is available at the end of the article
}

The aim of this study was to determine the frequency of COPD exacerbations in our ED, as well as the hospitalization-related factors.

\section{Methods}

This is a prospective observational study conducted in the ED of Salnés County Hospital, a 100-bed facility providing health coverage to 80,000 people, for one year (from March 1, 2009 to February 28, 2010), among patients admitted for COPD exacerbations. Included in the study there were patients with a COPD diagnosis confirmed by a doctor, and those patients with consistent clinical, radiological and epidemiological manifestations, typical symptoms, and smoking history greater than 10 pack years. The information was obtained from medical records and by interviewing patients during their stay in the ED. COPD severity was determined on the basis of the GOLD guidelines [11]. COPD exacerbation was defined as the sustained worsening of the patient's condition, from the stable state and beyond the normal dayto-day variations, that is acute in onset and necessitates a change in regular medication in a patient with underlying 
COPD [12]. Hospital admission was defined as admission to inpatient unit, observation unit, or intensive care unit after receiving the first care in the ED [8].

The following variables were analyzed:

1. Patient characteristics: age, gender, years of COPD evolution, that is the time elapsed from the COPD diagnosis or from the start of compatible symptoms referred by the patient till the moment of inclusion in the study; smoking status, categorized as "never smoker", "active smoker", "passive smoker" and "former smoker"; comorbidities; employment status, employed, unemployed, retired; reason for retirement, age, COPD, other diseases, and social support.

2. Characteristics of the underlying disease: COPD severity [11], patient regular treatment, previous treatment with systemic steroids, oxygen therapy at home, ED care and hospital admissions in the year before and in the year when the patient was enrolled in the study.

3. Data of current exacerbation: $\mathrm{O}_{2}$ saturation measured by pulse oximetry and vital signs, considering systolic hypotension SBP $<100 \mathrm{~mm} \mathrm{Hg}$, diastolic hypotension DBP $<60 \mathrm{~mm} \mathrm{Hg}$ and tachycardia heart rate $>100[13,14]$. Baseline oxygenation was stratified into two categories based on $\mathrm{SaO}_{2} / \mathrm{FiO}_{2}$ ratio, setting the cut off value at $90 \%$ saturation breathing room air, which corresponds to a value of 428.6. The analytical parameters included (hemoglobin, leukocytosis, neutrophilia and urea) were stratified into three categories: normal, high, low, according to the reference values in our medical laboratory. With regard to severity of the episode, the priority of care was based on the MTS (Manchester Triage System), which classifies the patient into five categories, enabling care prioritization according to patient severity: 1 = immediate: immediate attention; 2 = very urgent: care delayed up to 10 minutes; $3=$ urgent: 60 minutes; 4 = standard: 120 minutes; 5 = non-urgent: 240 minutes [15].

4. Treatments provided in the ED, and finally.

5. Data on the evolution of the exacerbation: length of stay in ED, patient destination, discharge or admission criteria.

\section{Statistical analysis}

The variables included in the study were analyzed on the basis of hospital admission for COPD exacerbation. Fisher's exact test and Chi-square test were used to compare categorical variables. T-Student test was used to analyze continuous variables following normal distribution, as well as Levene test to verify the homogeneity of the variances.
Mann-Whitney U-test was used for non-Gaussian distributions.

Likelihood of hospitalization was estimated by multivariate logistic regression, including in the analysis those variables that showed differences between patients admitted and not admitted with $p<0.1$. All data were analyzed with SPSS 15 for Windows.

\section{Results and discussion}

In the year of study, 409 exacerbations were registered in 239 patients (representing 1.07\% of all emergencies treated), with a rate of 1.12 episodes-day. $69 \%$ of patients came only once to the hospital. $79 \%$ out of 239 patients were male. The mean age was 75 years (ranging 41-96, SD 9.51). 57\% out of all exacerbations required admission. $11 \%$ out of all admissions were done in home care regime. Only one case required admission to the Intensive Care Unit (ICU). The admission decision was based on exacerbation severity as per clinical and analytical criteria in 61 patients, and the presence of decompensated comorbidity in 81 cases. The most frequent discharge reasons were mild COPD exacerbation or absence of respiratory failure after arterial blood gas measurement (data not shown). Univariate analysis revealed a higher frequency of hospital admissions in the following cases: those of highest priority for initial care according to the Manchester Scale (Types 1 and 2 account for most admissions); those with impaired oxygenation, higher respiratory effort, or requiring $\mathrm{O}_{2}$ administration; those receiving bronchodilator or steroid treatment in the $\mathrm{ED}$; and those with respiratory-infection related COPD exacerbation, with longer ED stays, or with a history of COPD-exacerbation related admissions (Table 1). Hospitalization-related factors in multivariate analysis were impaired oxygenation, presence of neutrophilia and administration of antibiotics in the ED (Table 2).

Exacerbations are a fundamental aspect of COPDgenerated costs [16]. The decision to admit a patient with COPD exacerbation is based on the interpretation of a series of clinical data, such as severity of dyspnea, respiratory failure, poor response to treatment during the stay in the ED, and presence of pneumonia or other comorbidities [17]. In our patients, as in other studies, the decompensation of underlying diseases is a frequent cause of hospitalization [18]. Determinants of hospital admission in COPD exacerbations in our environment depend mainly on some characteristics of the exacerbation, such as impaired oxygenation and the presence of neutrophilia. The other factor which proved to be an independent predictor of hospital admission was the decision to administer antibiotics by the ED, which also depends at least in part - on the exacerbation severity determined by the MD in charge.

Respiratory failure is one of the criteria that lead to the decision to grant hospital admission, together with 
Table 1 Demographic and clinical characteristics of patients assessed by the ED for COPD exacerbation, sorted by hospital admission

\begin{tabular}{|c|c|c|c|c|}
\hline Predictors & $\mathrm{N}$ & Not admitted & Admitted & p \\
\hline \multicolumn{5}{|l|}{ Gender } \\
\hline Male & $188(78.7 \%)$ & 78 (41.5\%) & $110(58.5 \%)$ & NS \\
\hline Female & $51(21.3 \%)$ & $22(43.1 \%)$ & 29 (56.9\%) & \\
\hline \multicolumn{5}{|l|}{ Age } \\
\hline$<65$ years & 37 (15.5\%) & $16(43.2 \%)$ & $21(56.8 \%)$ & NS \\
\hline $65-75$ years & $74(31.1 \%)$ & $30(40.5 \%)$ & 44 (59.5\%) & \\
\hline$>75$ years & 127 (53.4\%) & $54(42.5 \%)$ & 73 (57.5\%) & \\
\hline \multicolumn{5}{|l|}{ Manchester } \\
\hline 1 and 2 & $98(41.17 \%)$ & $24(24.5 \%)$ & 74 (75.5\%) & *** \\
\hline 3 & $100(42.0 \%)$ & $44(43.6 \%)$ & $56(56.4 \%)$ & \\
\hline 4 and 5 & $40(16.8 \%)$ & 32 (80.0\%) & $8(20.0 \%)$ & \\
\hline \multicolumn{5}{|l|}{ Gold } \\
\hline 0 & $102(42.7 \%)$ & $52(51.0 \%)$ & $50(49.0 \%)$ & * \\
\hline 1 and 2 & $61(25.5 \%)$ & $26(42.6 \%)$ & 35 (57.4\%) & \\
\hline 3 and 4 & 76 (31.8\%) & $22(28.9 \%)$ & $54(71.1 \%)$ & \\
\hline \multicolumn{5}{|l|}{ Smoker } \\
\hline No & $50(23.0 \%)$ & 24 (48.0\%) & $26(52.0 \%)$ & NS \\
\hline Yes & $34(15.7 \%)$ & $16(47.1 \%)$ & $18(52.9 \%)$ & \\
\hline Former smoker & 130 (59.9\%) & 51 (39.2\%) & 79 (60.8\%) & \\
\hline Passive smoker & $3(1.4 \%)$ & 1 (33.3\%) & $2(66.7 \%)$ & \\
\hline \multicolumn{5}{|l|}{ Tachypnea } \\
\hline No & 149 (62.3\%) & 76 (51.0\%) & $73(49.0 \%)$ & *** \\
\hline Yes & 90 (37.7\%) & $24(26.7 \%)$ & $66(73.3 \%)$ & \\
\hline \multicolumn{5}{|l|}{ SBP } \\
\hline$<100$ & $5(2.1 \%)$ & $2(40.0 \%)$ & $3(60.0 \%)$ & NS \\
\hline $100-140$ & $110(46.2 \%)$ & 47 (42.7\%) & $63(57.3 \%)$ & \\
\hline$>140$ & $123(51.7 \%)$ & $51(41.5 \%)$ & 72 (58.5\%) & \\
\hline \multicolumn{5}{|l|}{ DBP } \\
\hline$<60$ & $31(13.5 \%)$ & $11(35.5 \%)$ & $20(64.5 \%)$ & NS \\
\hline $60-90$ & 174 (76.0\%) & 77 (44.3\%) & 97 (55.4\%) & \\
\hline$>90$ & $24(10.5 \%)$ & $12(35.3 \%)$ & $22(64.7 \%)$ & \\
\hline \multicolumn{5}{|l|}{$\mathrm{T}^{\mathrm{a}}$} \\
\hline$<37^{\circ} \mathrm{C}$ & 172 (72.0\%) & 79 (45.9\%) & 93 (54.1\%) & * \\
\hline$>37 C$ & 67 (28.0\%) & 21 (31.3\%) & 46 (68.7\%) & \\
\hline \multicolumn{5}{|l|}{ HR } \\
\hline$<100$ & $156(65.5 \%)$ & 74 (47.4\%) & 82 (56.2\%) & $*$ \\
\hline$>100$ & 82 (34.5\%) & 25 (30.5\%) & 57 (69.5\%) & \\
\hline \multicolumn{5}{|l|}{$\mathrm{SaO}_{2} / \mathrm{FiO}_{2}$} \\
\hline$<428.6$ & 84 (35.1\%) & 8 (9.5\%) & 76 (90.5\%) & *** \\
\hline$>428.6$ & 155 (64.9\%) & $92(59.4 \%)$ & $63(40.6 \%)$ & \\
\hline
\end{tabular}


Table 1 Demographic and clinical characteristics of patients assessed by the ED for COPD exacerbation, sorted by hospital admission (Continued)

\begin{tabular}{|c|c|c|c|c|}
\hline \multicolumn{5}{|l|}{$\mathrm{O}_{2}$ at Home } \\
\hline No & $196(82.0 \%)$ & $85(43.4 \%)$ & $111(56.6 \%)$ & NS \\
\hline Yes & $43(18.0 \%)$ & $15(34.9 \%)$ & $28(65.1 \%)$ & \\
\hline \multicolumn{5}{|l|}{ Baseline Treatment } \\
\hline Oral Corticosteroids & $16(6.7 \%)$ & $6(37.5 \%)$ & $10(62.5 \%)$ & NS \\
\hline Anticholinergics and/or saba and/or laba & $26(11.3 \%)$ & $8(30.8 \%)$ & $18(69.2 \%)$ & \\
\hline Anticholinergics and/or saba and/or laba + Inhaled Corticosteroids & $140(58.3 \%)$ & $63(45.0 \%)$ & $77(55.0 \%)$ & \\
\hline None of these (ALT, Theophylline..) & $55(22.9 \%)$ & $23(41.8 \%)$ & $32(58.2 \%)$ & \\
\hline \multicolumn{5}{|l|}{ ED Treatment } \\
\hline \multicolumn{5}{|l|}{ Antibiotics } \\
\hline No & $102(43.4 \%)$ & $61(59.8 \%)$ & $41(40.2 \%)$ & *** \\
\hline Yes & $133(56.6 \%)$ & $39(29.3 \%)$ & $94(70.7 \%)$ & \\
\hline \multicolumn{5}{|l|}{$\mathrm{O}_{2}$} \\
\hline No & $26(11.1 \%)$ & $23(88.5 \%)$ & $3(11.5 \%)$ & *** \\
\hline Yes & $209(88.9 \%)$ & $77(36.8 \%)$ & $132(63.2 \%)$ & \\
\hline \multicolumn{5}{|l|}{ Systemic Corticosteroids } \\
\hline No & $64(27.2 \%)$ & $40(62.5 \%)$ & $24(37.5 \%)$ & *** \\
\hline Yes & $171(72.8 \%)$ & $60(35.1 \%)$ & $111(64.9 \%)$ & \\
\hline \multicolumn{5}{|l|}{ Inhaled/Nebulized Cortocosteroids } \\
\hline No & $183(76.6 \%)$ & $85(46.4 \%)$ & $98(53.6 \%)$ & ** \\
\hline Yes & $56(23.4 \%)$ & $15(26.8 \%)$ & $41(73.2 \%)$ & \\
\hline \multicolumn{5}{|l|}{ Any Nebulized Drugs } \\
\hline No & $44(18.4 \%)$ & $22(50.0 \%)$ & $22(50.0 \%)$ & NS \\
\hline Yes & $195(81.6 \%)$ & $78(40 \%)$ & $117(60 \%)$ & \\
\hline \multicolumn{5}{|l|}{ Beta-agonists } \\
\hline No & $39(16.3 \%)$ & $24(61.5 \%)$ & $15(38.5 \%)$ & ** \\
\hline Yes & $200(83.7 \%)$ & $76(38.0 \%)$ & $124(62.0 \%)$ & \\
\hline \multicolumn{5}{|l|}{ Anticholinergics } \\
\hline No & $40(17.1 \%)$ & $23(57.5 \%)$ & $17(42.5 \%)$ & * \\
\hline Yes & $194(82.9 \%)$ & 77 (39.7\%) & $117(60.3 \%)$ & \\
\hline \multicolumn{5}{|l|}{ Anti-Leukotrienes } \\
\hline No & $232(98.7 \%)$ & $100(43.1 \%)$ & $132(56.9 \%)$ & NS \\
\hline Yes & $3(1.3 \%)$ & $0(0.0 \%)$ & $3(100 \%)$ & \\
\hline \multicolumn{5}{|l|}{ Theophyllines } \\
\hline No & $231(98.3 \%)$ & 99 (42.9\%) & $132(57.1 \%)$ & NS \\
\hline Yes & $4(1.7 \%)$ & $1(25.0 \%)$ & $3(75.0 \%)$ & \\
\hline \multicolumn{5}{|l|}{ Mucolytics } \\
\hline No & $206(87.7 \%)$ & $87(42.2 \%)$ & 119 (57.8\%) & NS \\
\hline Yes & $29(12.3 \%)$ & $13(44.8 \%)$ & $16(55.2 \%)$ & \\
\hline \multicolumn{5}{|l|}{ Month } \\
\hline January-March & $78(32.6 \%)$ & $33(42.3 \%)$ & $45(57.7 \%)$ & NS \\
\hline April-June & $59(24.7 \%)$ & $23(39.0 \%)$ & $36(61.0 \%)$ & \\
\hline July-September & $52(21.8 \%)$ & $23(44.2 \%)$ & $29(55.8 \%)$ & \\
\hline October-December & $50(20.9 \%)$ & 21 (42.0\%) & $29(58.0 \%)$ & \\
\hline
\end{tabular}


Table 1 Demographic and clinical characteristics of patients assessed by the ED for COPD exacerbation, sorted by hospital admission (Continued)

\begin{tabular}{|c|c|c|c|c|}
\hline \multicolumn{5}{|l|}{ Day of the Week } \\
\hline Monday-Thursday & $150(62.8 \%)$ & $62(41.3 \%)$ & $88(58.7 \%)$ & NS \\
\hline Friday-Sunday & $89(37.2 \%)$ & $38(42.7 \%)$ & $51(57.3 \%)$ & \\
\hline \multicolumn{5}{|l|}{ Time } \\
\hline 0-8:00 & $38(15.9 \%)$ & $12(31.6 \%)$ & $26(68.4 \%)$ & NS \\
\hline 8:00-16:00 & $113(47.3 \%)$ & $48(42.5 \%)$ & $65(57.5 \%)$ & \\
\hline $16: 00-24: 00$ & $88(36.8 \%)$ & $40(45.5 \%)$ & $48(54.5 \%)$ & \\
\hline \multicolumn{5}{|l|}{ Hospital Readmissions } \\
\hline None & $201(84.1 \%)$ & $90(44.8 \%)$ & $111(55.2 \%)$ & * \\
\hline Any (Early or Late) & $38(15.9 \%)$ & $10(26.3 \%)$ & $28(73.7 \%)$ & \\
\hline \multicolumn{5}{|l|}{ ED Readmissions } \\
\hline None & $228(95.4 \%)$ & $96(42.1 \%)$ & $132(57.9 \%)$ & NS \\
\hline Any (Early or Late) & $11(4.6 \%)$ & $4(36.4 \%)$ & $7(63.6 \%)$ & \\
\hline \multicolumn{5}{|l|}{ Number of Admissions } \\
\hline None & $82(34.3 \%)$ & 79 (96.3\%) & $3(3.7 \%)$ & $* * *$ \\
\hline One & $120(50.2 \%)$ & $12(10.0 \%)$ & $108(90.0 \%)$ & \\
\hline Two or More & $37(15.5 \%)$ & $9(24.3 \%)$ & $28(75.7 \%)$ & \\
\hline \multicolumn{5}{|l|}{ Number of Emergencies } \\
\hline One & $166(69.5 \%)$ & $64(38.6 \%)$ & $102(61.4 \%)$ & NS \\
\hline Two & $33(13.8 \%)$ & $16(48.5 \%)$ & $17(51.5 \%)$ & \\
\hline Three or More & $40(16.7 \%)$ & $20(50.0 \%)$ & $20(50.0 \%)$ & \\
\hline \multicolumn{5}{|c|}{ Length of the Crisis (Hours) } \\
\hline$<12$ & $23(10.8 \%)$ & $9(39.1 \%)$ & $14(60.9 \%)$ & NS \\
\hline $12-24$ & $35(16.4 \%)$ & $10(28.6 \%)$ & $25(71.4 \%)$ & \\
\hline $24-72$ & $29(13.6 \%)$ & $11(37.9 \%)$ & $18(62.1 \%)$ & \\
\hline$>72$ & $126(59.2 \%)$ & $58(46.0 \%)$ & $68(54.0 \%)$ & \\
\hline \multicolumn{5}{|c|}{ Length of ED Stay (Hours) } \\
\hline$<4$ & $63(27.8 \%)$ & $38(60.3 \%)$ & $25(39.7 \%)$ & $* * *$ \\
\hline $4-8$ & $50(22.0 \%)$ & $23(46.0 \%)$ & $27(54.0 \%)$ & \\
\hline $8-18$ & $58(25.5 \%)$ & $20(34.5 \%)$ & $38(65.5 \%)$ & \\
\hline$>72$ & $126(24.7 \%)$ & $11(19.6 \%)$ & $45(80.4 \%)$ & \\
\hline \multicolumn{5}{|l|}{ Hemoglobin } \\
\hline Low & $106(44.7 \%)$ & $46(43.4 \%)$ & $60(56.6 \%)$ & NS \\
\hline Normal & $128(54 \%)$ & $52(40.6 \%)$ & $76(59.4 \%)$ & \\
\hline High & $3(1.3 \%)$ & $0(0.0 \%)$ & $3(100.0 \%)$ & \\
\hline \multicolumn{5}{|l|}{ Leukocytes } \\
\hline Leukopenia & $5(2.1 \%)$ & $3(60.0 \%)$ & $2(40.0 \%)$ & *** \\
\hline Normal & $154(64.4 \%)$ & $79(51.3 \%)$ & $75(48.7 \%)$ & \\
\hline Leukocytosis & $80(33.5 \%)$ & $18(22.5 \%)$ & $62(77.5 \%)$ & \\
\hline \multicolumn{5}{|l|}{ Neutrophil count } \\
\hline Low & $3(1.3 \%)$ & $1(33.3 \%)$ & $2(66.7 \%)$ & $* * *$ \\
\hline Normal & $127(53.1 \%)$ & $69(54.3 \%)$ & $58(45.7 \%)$ & \\
\hline High & $109(45.6 \%)$ & $30(27.5 \%)$ & 79 (72.5\%) & \\
\hline
\end{tabular}


Table 1 Demographic and clinical characteristics of patients assessed by the ED for COPD exacerbation, sorted by hospital admission (Continued)

\begin{tabular}{|c|c|c|c|c|}
\hline \multicolumn{5}{|l|}{ Urea } \\
\hline Low & $4(1.8 \%)$ & $2(50.0 \%)$ & 2 (50.0\%) & NS \\
\hline Normal & $120(52.6 \%)$ & $54(45 \%)$ & $66(55.0 \%)$ & \\
\hline High & $104(45.6 \%)$ & $33(31.7 \%)$ & $71(68.3 \%)$ & \\
\hline \multicolumn{5}{|c|}{ Emergencies the Year Before } \\
\hline None & $150(62.7 \%)$ & 59 (39.3\%) & $91(60.7 \%)$ & NS \\
\hline One & 37 (15.5\%) & $19(51.4 \%)$ & $18(48.6 \%)$ & \\
\hline Two or More & $52(21.8 \%)$ & $22(42.3 \%)$ & $30(57.7 \%)$ & \\
\hline \multicolumn{5}{|c|}{ Hospital Admissions the Year Before } \\
\hline None & $178(75.1 \%)$ & $75(42.1 \%)$ & $103(57.9 \%)$ & NS \\
\hline One & $37(15.6 \%)$ & $16(43.2 \%)$ & $21(56.8 \%)$ & \\
\hline Two or More & 22 (9.3\%) & 7 (31.8\%) & 15 (68.2\%) & \\
\hline
\end{tabular}

exacerbation severity and even the need for mechanical ventilation in patients with COPD exacerbations [19].

In our study, oxygenation - assessed by the $\mathrm{SaO}_{2} / \mathrm{FiO}_{2}$ ratio - was lower in patients who were admitted, indicating the severity of the exacerbation or of the underlying disease [19].

Given its simplicity, pulse oximetry seems to be a particularly useful method to assess oxygenation in patients with COPD exacerbation: it does not require special training, is reliable in the range of $80-100 \%$ saturation and, although it is not a substitute for blood gas measurement, it provides real time, continuous and non-invasive monitoring of heart rate, can alert on tissue perfusion decreases [20], and detect hypoxia with high sensitivity and specificity [21].

Although pulse oximetry provides guidance on the initial need for oxygen therapy, arterial blood gas measurement is essential to assess potential hypercapnia and acidosis [11]

Inflammatory markers could also be used as a parameter to assess the severity of COPD exacerbations [22]. One of the systemic markers of inflammation is the neutrophil count in peripheral blood, which is higher in bacterial exacerbations [23]. Some authors report significant relationship between neutrophilia in peripheral blood, exacerbation severity and hospital admission frequency in COPD exacerbations $[24,25]$. In our case, neutrophil count in peripheral

Table 2 Predictors of hospital admission according to multivariate analysis

\begin{tabular}{lccc}
\hline Factors & OR & Cl 95\% & p \\
\hline Neutrophilia & 3.15 & $(1.570,6.335)$ & $* *$ \\
$\mathrm{SaO}_{2} / \mathrm{FiO}_{2}>428.6$ & 0.080 & $(0.034,0.187)$ & $* * *$ \\
Antibiotics & 2.175 & $(1.081,4.376)$ & $*$ \\
\hline
\end{tabular}

${ }^{*} p<0.05$.

${ }^{* *} p<0.01$

${ }^{* * *} p<0.001$. blood was significantly higher among those admitted, so neutrophilia could be a particularly important indicator in the initial exacerbation assessment in those patients.

The causes of exacerbations are not always known and, in connection with the latter, also the optimal treatment, that should logically be different according to exacerbation etiology. In our study, the initial decision by the ED doctor to start an antibiotic treatment appears to be associated with a higher likelihood of hospital admission, regardless of both patient baseline and exacerbation severity. Since the indication of antibiotic treatment in COPD exacerbations is not clearly established [26-28], this decision could be based on clinical criteria [29], and even in those cases where the likelihood of bacterial infectious etiology is not evident, some doctors may consider antibiotic prescription to be safer [28].

Antibiotic treatment seems to be beneficial in most severe exacerbations and in those cases with high clinical likelihood of infection [30-32]. Also, antibiotic prescription in COPD exacerbations which require hospital admission is widespread [26]. These facts may condition the prescription of antibiotic treatment in the ED to change the perception of COPD exacerbation severity by the doctors who eventually request patient admission, regardless of objective criteria: the start of antibiotic treatment in the ED means to increase the likelihood of hospital admission by more than twice.

\section{Conclusions}

In conclusion, COPD exacerbations account for over 1\% of all visits to our ED, $57 \%$ of which will require hospitalization. Impaired oxygenation, higher peripheral blood neutrophilia and antibiotic prescription in the ED are associated with a greater likelihood of hospitalization in COPD exacerbations assessed in the ED. 


\section{Competing interests}

The authors declare that they have no competing interests.

\section{Author details}

${ }^{1}$ Emergency Department, Salnés County Hospital, Ande-Rubiáns s/n, Vilagarcía de Arousa, Pontevedra, Spain. ${ }^{2}$ Family and Community Medicine, Hospital Complex of Pontevedra, Pontevedra, Spain. ${ }^{3}$ Pneumology Service, Hospital Complex of Pontevedra, Pontevedra, Spain.

Received: 10 May 2012 Accepted: 19 June 2012

Published: 19 June 2012

\section{References}

1. World Health Organization: World Health Report. Geneva, Switzerland: WHO 2000. http://www.who.int/whr/2000. Accessed Jan 14; 2009.

2. Chapman KR, Mannino DM, Soriano JB, Vermeire PA, Buist AS, Thun MJ, Connell C, Jemal A, Lee TA, Miravitlles M, Aldington S, Beasley R: Epidemiology and costs of chronic obstructive pulmonary disease. Eur Respir J 2006, 27:188-207.

3. Peña VS, Miravitlles M, Gabriel R, Jiménez-Ruiz CA, Villasante C, Masa JF, Viejo $J$, Fernández-Fau L: Geographic variations in prevalence and underdiagnosis of COPD: results of the IBERPOC multicentre epidemiological study. Chest 2000, 118:981-989.

4. de Batlle J, Romieu I, Antó J, Méndez M, Rodríguez E, Balcells E, Ferrer A, Gea J, Rodriguez-Roisin R, Garcia-Aymerich J: PAC-COPD Study Group. Dietary habits of firstly admitted Spanish COPD patients. Respir Med 2009, 103:1904-1910.

5. Alvarez-Sala J, Cimas E, Masa J, Miravitlles M, Molina J, Naberan K, Simonet P, Viejo J, Grupo de Trabajo de la Sociedad Española de Neumología y Cirugía Torácica (SEPAR); Sociedad Española de Medicina de Familia y Comunitaria (semFYC): Recommendations for the care of the patient with chronic obstructive pulmonary disease. Arch Bronconeumol 2001, 37:269-278.

6. Soler JJ, Sánchez L, Román P, Martínez M, Perpiñá M: Risk factors of emergency care and admission in COPD patients with high consumption of health resources. Respir Med 2004, 98:318-329.

7. Cydulka RK, Rowe BH, Clark S, Emerman CL, Rimm AR, Camargo CA Jr: Gender differences in emergency department patients with chronic obstructive pulmonary disease exacerbation. Acad Emerg Med 2005, 12:1173-1179.

8. Tsai C, Clark S, Cydulka RK, Rowe BH, Camargo CA Jr: Factors associated with hospital admission among emergency department patients with chronic obstructive pulmonary disease exacerbation. Acad Emerg Med 2007, 14:6-15.

9. Cydulka RK, Rowe BH, Clark S, Emerman CL, Camargo CA Jr: MARC Investigators. Emergency department management of acute exacerbations of chronic obstructive pulmonary disease in the ederly: the Multicenter Airway Research Collaboration. J Am Geriatr Soc 2003, 51:908-916.

10. Gonzalez-Barcala F, Aboal J, Valdes L, Carreira JM, Alvarez-Dobaño JM, Puga A, Garcia-Sanz MT, Takkouce B: Trends in adult asthma hospitalization: genderage effect. Multidiscip Resp Med 2011, 6:82-86.

11. Global initiative for Chronic Obstructive Lung Disease. http://www.goldcopd. com/Guidelineitem.asp? $11=2 \& \mid 2=1$ \&intld $=989$.

12. Rodriguez-Roisin R: Toward a consensus definition for COPD exacerbations. Chest 2000, 117(5 Suppl 2):398S-401S.

13. Jones A, Yiannibas V, Johnson C, Kline JA: Emergency department hypotension predicts sudden unexpected in-hospital mortality: a prospective cohort study. Chest 2006, 130:941-946.

14. Saldías-Peñafiel F, O'Brien-Solar A, Gederlini-Gollerino A, Farías-Gontupil G, Díaz-Fuenzalida A: Community-acquired pneumonia requiring hospitalization in immunocompetent elderly patients:clinical features, prognostic factors and treatment. Arch Bronconeumol 2003, 39:333-340.

15. Descripción del Sistema Manchester. Grupo Español de Triage Manchester. http//www. triagemanchester.com/Descripcion2.htm. Accessed Jan 15;2011.

16. Lusuardi M, Lucioni C, Donners CF: Cost related to COPD exacerbations in Italy. Multidiscip Resp Med 2008, 3:60-62.

17. American Thoracic Society and European Respiratory Society. Standards for the diagnosis and management of patients with COPD. http://www.thoracic. org/clinical/copd-guidelines/resources/copddoc.pdf.

18. Roca B, Almagro P, López F, Cabrera FJ, Montero L, Morchón D, Díez J, de la Iglesia F, Fernández M, Castiella J, Zubillaga E, Recio J, Soriano JB, ECCO Working Group on COPD; Spanish Society of Internal Medicine: Factors associated with mortality in patients with exacerbation of chronic obstructive pulmonary disease hospitalized in General Medicine departments. Intern Emerg Med 2011, 6:47-54.
19. Carrera M, Sala E, Cosío BG, Agustí AG: Hospital treatment of chronic obstructive pulmonary disease exacerbations: an evidence-based review. Arch Bronconeumol 2005, 41:220-229.

20. Hanning CD, Alexander-Williams JM: Pulse oximetry: a practical review. BMJ 1995, 311:367-370

21. Güryay MS, Ceylan E, Günay T, Karaduman S, Bengi F, Parlak I, Ciçek M, Cimrin AH: Can Spirometry, pulse oximetry and dyspnea scoring reflect respiratory failure in patients with chronic obstructive pulmonary disease exacerbation? Med Princ Pract 2007, 16:378-383.

22. Chronic obstructive pulmonary disease: management of chronic obstructive pulmonary disease in adults in primary and secondary care. National Clinical Guideline Centre 2004 Royal College of Physicians of London. http://www. nice.org.uk/nicemedia/live/13029/49425/49425.pdf.

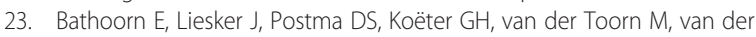
Heide S, Ross HA, van Oosterhout AJ, Kerstiens HA: Change in inflammation in out-patient COPD patients from stable phase to a subsequent exacerbation. Int J Chron Obstruct Pulmon Dis 2009, 4:101-109.

24. Papi A, Belletato CM, Braccioni F, Romagnoli M, Casolari P, Caramori G, Fabbri LM, Johnston SL: Infections and airway inflammation in chronic obstructive pulmonary disease severe exacerbations. Am J Respir Crit Care Med 2006, 173:1114-1121.

25. Velthove KJ, Bracke M, Souverein PC, Schweizer RC, Ten Berg MJ, Leufkens $H G$, van Solinge WW: Identification of exacerbations in obstructive lung disease through biomarkers. Biomarkers 2009, 14:523-528.

26. Soler N: Systemic markers of exacerbated chronic obstructive pulmonary disease: how they can help with the decision of whether or not to prescribe antibiotics. Arch Bronconeumol 2008, 44:581-583.

27. Puhan MA, Vollenweider D, Steurer J, Bossuyt P, Ter Riet G: Where is the supporting evidence for treating mild to moderate chronic obstructive pulmonary disease exacerbations with antibiotics? A systematic review. BMC Med 2008, 6:28.

28. Puhan MA, Vollenweider D, Latshang T, Steurer J, Steurer-Stey C: Exacerbations of chronic obstructive pulmonary disease: when are antibiotics indicated? A systematic review. Respir Res 2007, 8:30.

29. Anthonisen NR, Manfreda J, Warren CP, Hershfield ES, Harding GK, Nelson NA: Antibiotic therapy in exacerbations of chronic obstructive pulmonary disease. Ann Intern Med 1987, 106:196-204.

30. Iyer-Parameswaran G, Murphy TF: Chronic obstructive pulmonary disease: role of bacteria and updated guide to antibacterial selection in the older patient. Drugs Aging 2009, 26:985-995.

31. Miravitlles M, Monsó E, Mensa J, Aguarón Pérez J, Barberán J, Bárcena Caamaño M, Cañada Merino JL, Martínez Ortiz de Zárate M, Moya Mir MS, Picazo JJ, Quintano Jiménez JA, García-Rodríguez JA: Antimicrobial treatment of exacerbation in chronic obstructive pulmonary disease: 2007 consensus statement. Arch Bronconeumol 2008, 44:100-108.

32. Guía de práctica clínica de diagnóstico y tratamiento de la Enfermedad Pulmonar Obstructiva Crónica. SEPAR-ALAT, 2009. www.separ.es.

doi:10.1186/2049-6958-7-6

Cite this article as: García-Sanz et al:: Factors associated with hospital admission in patients reaching the emergency department with COPD exacerbation. Multidisciplinary Respiratory Medicine 2012 7:6.

\section{Submit your next manuscript to BioMed Central and take full advantage of:}

- Convenient online submission

- Thorough peer review

- No space constraints or color figure charges

- Immediate publication on acceptance

- Inclusion in PubMed, CAS, Scopus and Google Scholar

- Research which is freely available for redistribution 